\section{幽闹 Digital Commons@}

Loyola Marymount University

LMU Loyola Law School
Loyola of Los Angeles International and Comparative Law Review

Volume 37 | Number 1

Article 1

Summer 7-1-2015

\title{
Towards an Internet Bill of Rights
}

Giovanna De Minico

Follow this and additional works at: https://digitalcommons.Imu.edu/ilr

Part of the Communications Law Commons, Comparative and Foreign Law Commons, International Law Commons, and the Internet Law Commons

\section{Recommended Citation}

Giovanna De Minico, Towards an Internet Bill of Rights, 37 Loy. L.A. Int'I \& Comp. L. Rev. 1 (2015). Available at: https://digitalcommons.Imu.edu/ilr/vol37/iss1/1

This Article is brought to you for free and open access by the Law Reviews at Digital Commons @ Loyola Marymount University and Loyola Law School. It has been accepted for inclusion in Loyola of Los Angeles International and Comparative Law Review by an authorized administrator of Digital Commons@Loyola Marymount University and Loyola Law School. For more information, please contact digitalcommons@lmu.edu. 


\title{
Towards an Internet Bill of Rights
}

\author{
Giovanna De Minico*
}

\section{SOME QUESTIONS TO BE ANSWERED}

This work seeks to spark some questions about what rules might be set up for the Internet and what the goals of these rules should be.

The first question examined is whether a binding regulation of the Internet is required. This debate is mainly propelled by the American doctrine, ${ }^{1}$ a doctrine divided between the champions of unchecked selfregulation - drawn by the network providers themselves ${ }^{2}$ - and those in favour of an absorbing intervention by an authority. ${ }^{3}$ The second question explored is whether a binding regulation would require a formal modification of national Constitutions eschewing any reference to the Internet. This article intends-to detail and explore a third alternative: the proposal of a specific and supranational "Bill of rights" for the Internet.

This proposal prompts further questions: which legislative body should write this Bill? What should the relationship be between binding

\footnotetext{
* Professor of Constitutional Law and of Information and Communication Law, Law Department, University of Naples, Federico II. Visiting Fellow at the London School of Economics. Director of the University Interdepartmental Research Centre Ermes (www.ermes.unina.it). I would like to thank Professors Andrew Murray (LSE, London) for his enlightening discussions and Massimo Villone (Federico II, Naples) for many stimulating suggestions. I would also like to thank the dedicated staff of Loyola's International and Comparative Law Review for their helpful feedback during the editing process.
}

1. DAWn C. NunZiato, ViRTUAL FreEdom 97-100 (2009).

2. John Mathiason, Internet Governance: The NeW Frontier of Global Institutions 70-96 (2009); see David R. Johnson \& David Post, Law and Borders: The Rise of Law in Cyberspace, 48 STAN. L. REV. 1367, 1371-1380 (1996).

3. John Perry Barlow, A Declaration of the Independence of Cyberspace (Feb. 8, 1996), http://projects.eff.org/ barlow/Declaration-Final.html; Joel Reidenberg, Governing Networks and Rule-Making in Cyberspace, 45 EMORY L.J. 911, 913 (1996) (discussing paternalism). For a balanced critique to this approach, see ANDREW MuRRAY, THE REGULATION OF CYBERSPACE: CONTROL IN THE ONLINE ENVIRONMENT (2006). Others prefer a transfer of the offline rules to the online universe while others reconsider the necessity of an ad hoc regulation in the case of human rights. Compare Julie E. Cohen, Cyberspace As/And Space, 107 Colum. L. REV. 210 (2007) with Robin Mansell, Human Rights and Equity in Cyberspace, in HUMAN RIGHTS IN THE Digital AgE 1-10 (Andrew D. Murray \& Matthias Klang eds., 2004). 
rules and the policies of self-regulation? What kind of content would be appropriate or necessary to put in the Bill? Should the Bill give greater weight to fundamental rights than to economic interests? Should supranational case law be a contributing source to the Bill, and if so, to what extent?

To answer these questions, I will not simply tackle a single freedom concerning netizens. This article's analysis will instead focus on the basic need that fundamental rights, normally protected by national constitutions, should receive universal protection regardless of its territorial boundaries, in accordance with the a-territorial nature of the Internet. Therefore, rather than focusing on specific rights, whether they be freedom of expression, communication, or the right to access the Internet, ${ }^{4}$ this article intends to propose the essentials of a statute for fundamental rights, one that is sufficiently general to encompass every freedom, regardless of its specific features. This statute should also be supranational so that every freedom is consistent regardless of the variances in different nations. This would also ensure equality of treatment.

National instances have given rise to a fragmented and irregular juridical mosaic. Since national legislations are primarily based on the specific problems of each legal system and tradition, they therefore vary in scope and content. The U.S. juridical tradition, for instance, has given particular relevance to some norms ${ }^{5}$ that help set the boundaries for public powers on copyright law. In the U.K., this same problem has been tackled by essentially looking at the relationships between soft law and binding rules in order to affirm the primacy of a binding framework, ${ }^{6}$ in particular, a new copyright concept well-suited to the digital age. ${ }^{7}$ In France, in the absence of more comprehensive rules, the attention of then-President Sarkozy turned toward the publishing interests of record

4. Giovanna De Minico, New Social Rights and Internet: Which Policies Combine Them, 15 INTER. COMM. L. REV. 261 (2013). For a wide overview on specific rights, see Michael Boardman, Digital Copyright Protection and Graduated Response: A Global Perspective, 33 Loy. L.A. InT'L \& CoMP. L. REV. 223, 235-243 (2011) [hereinafter Digital Copyright Protection and Graduated Response: A Global Perspective].

5. S. $968112^{\text {th }}$ Cong., (2011); See also S. $3261112^{\mathrm{TH}}$ Congress; See Annemarie Bridy, Copyright Policymaking as Procedural Democratic Process: A Discourse-Theoretic Perspective on ACTA, SOPA, and PIPA, 30 CARDOZO ARTS \& ENT. L.J. $105^{\mathrm{TH}}$ Congress, Digital Millennium Copyright Act, October 28, 1998 (better known as DMCA, this is an example of regulation).

6. For a discussion of possible relationships between self-regulation and binding rules, see Julia Black, Constitutionalizing self-regulation, MoD. L. REV. 1, 27 (1996).

7. JERry JiE Hua, TOWARD a MORE BALANCED APPROACH: RETHINKING AND READJUSTING COPYRIGHT SySTEMS IN THE Digital NETWORK ERA 141 (Heidelberg: Springer, 2014). 
and film companies, which led to a legislation in 2009 that primarily focused on creating stringent copyright protection. ${ }^{8}$ In Italy, a substantial lack of legislative attention on Internet-related issues has been superseded by a very controversial initiative by the competent national $\mathrm{Au}-$ thority. ${ }^{9}$ Finally, the European Court of Justice has extensively used the European Union Regulation on E-Commerce addressing the issue of Internet Service Provider accountability. ${ }^{10}$

These instances clearly prove the existence of an uneven framework born out of occasional pressures and initiatives. This further underlines the necessity of general regulations that extend beyond both national boundaries and the sectional interests prevailing in any given moment. A comprehensive view of the possible answers will support the assertion that all technical issues concerning the Internet cannot be left to the invisible hand of a market-oriented technological development, rather, it should be goal-oriented towards achieving a common good. Should this happen, the Internet would finally be a unique and effective opportunity for everyone to pursue personal growth and participation in the virtual political process. Such an outcome, however, can only be ensured through clear choices made by policymakers and netizens. To outline which choices should be adopted, and how they should be adopted, is the main goal of this article.

8. In the doctrine : Michael Boardman, Digital Copyright Protection and Graduated Response: A Global Perspective, supra note 4, at 228-229.

See Loi 2009-669 du 12 juin 2009 favorisant la diffusion et la protection de la création sur internet [Law 2009-669 of June 12, 2009 in favor of the districtuion and protection of Copyright on the Internet], Journal Officiel de la République Française [J.O.] [OFFICIAL JOURNAL OF FRANCE], available

http://www.legifrance.gouv.fr/affichTexte.do?cidTexte=JORFTEXT000020735432\&categorieLie $\mathrm{n}=\mathrm{id}$. On this law the Conseil Constitutionnel intervened with the Décision $\mathrm{n}^{\circ}$ 2009-580 DC, 10 june 200 and declared the unconstitutionality of the provisions 5 and 11, at http://www.conseilconstitutionnel.fr/decision/2009/2009-580-dc/decision-n-2009-580-dc-du-10-juin-

2009.42666.html.

9. The Authority for Communication Guarantees of Italy (AGCOM) adopted a controversial regulation on Internet copyright. See Delibera n. 680/13/CONS [Deliberation $n$. 680/13/CONS], available at http://www.agcom.it/default.aspx?DocID=12228. A closer look will be given to this act in the following pages of this work, infra parag. 3.1.

10. See Case C-70/10 Scarlet Extended SA v. Société belge des auteurs, compositeurs et éditeurs SCRL (SABAM), $2011 \quad$ E.C.R. I-11959 available at http://curia.europa.eu/juris/document/document.jsf?text=\&docid=115202\&pageIndex $=0 \&$ doclan $\mathrm{g}=\mathrm{EN} \&$ mode $=\mathrm{req} \& \mathrm{dir}=\& \mathrm{occ}=$ first\&part $=1 \& \mathrm{cid}=153683$; see also Joined Cases C-236/08 to C238/08, Google France SARL v. Louis Vuitton Malletier SA, 2010 E.C.R. I-2467, available at http://curia.europa.eu/juris/document/document.jsf?text=\&docid=83961\&pageIndex=0\&doclang $=\mathrm{EN} \&$ mode $=1$ st $\&$ dir $=\&$ occ $=$ first $\&$ part $=1 \&$ cid $=154007$.

See generally Mario Viola De Azavedo Cunha et al., Peer-to-peer privacy violations and ISP liability:data protection in the user-generated web, INT'L DATA PRIVACY L., 50, $55-58$ (2012). 


\section{THE AVAILABLE ALTERNATIVES: SELF-REGULATION OR BINDING RULES?}

The first step of the inquiry is to consider whether a heteronomous system of regulation, or self-regulation, should be pursued for the Internet, keeping in mind that self-regulation is an inherently multifaceted notion. ${ }^{1}$

A direct connection exists between the legal value of selfregulation and its conformity with the relevant legal systems. ${ }^{12}$ Acts of self-regulation, if public powers adequately defined their content and if authority is vested onto its authors, deserve a place in the conversation next to binding sources. This is contrary to the case of unfettered selfregulations.

There may be the case of a State leaving all initiative to private bodies, getting involved only when self-regulation is missing. This form of self-regulation takes place within the limits of the freedom of negotiation, ${ }^{13}$ as long as no problem arises, the State does not directly intervene. Nevertheless, the fact that the state may act turns that absence into a potential presence on the assumption that "if nothing is done State action will follow." 14 This self-regulation model may be defined as "independent" from the law since the law is entirely lacking, even as a minimal framework for the inter partes negotiation. ${ }^{15}$ This is a historically regressive model. ${ }^{16}$ Private stakeholders, when left by themselves, have shown time and time again that they pursue only egotistical interests. ${ }^{17}$

11. Linda SENDEN, Soft LAW In EuRopean COMMUnity LAW 118-20 (2004).

12. See Anthony Ogus, Rethinking Self-Regulation, 15 OX. J. L. STUD. 97-108 (1995) [hereinafter Rethinking Self-Regulation]; see also Anthony I. Ogus, Regulatory Paternalism: When is it Justified, in CORPORATE GOVERNANCE IN CONTEXT: CORPORATION, STATES, AND MARKETS IN EUROPE, JAPAN, AND THE US 304-20 (Klaus J. Hoptet al. eds., 2004) [hereinafter Regulatory Paternalism].

13. Rethinking Self-Regulation, supra note 12, at 101.

14. ROBERT BALDwin \& MARTin CAVE, Understanding REgulation: TheORY, STRATEGY, AND PRACTICE 126 (1999).

15. Giovanna De Minico, A Hard Look at Self-Regulation in the UK, 1 EUR. BUS. L. REV. 211 (2006) [hereinafter A Hard Look] (I classified this model as "independent" because the term appropriately describes a regulation operating outside of a legal framework, therefore coming close to a praeterlegem rulemaking); see also Linda Senden, Soft Law, Self-Regulation and CoRegulation in European Law: Where Do They Meet?, 9.1 ELEC. J. COMP. L. 12 (2005).

16. A Hard Look, supra note 15 , at 188-89. The example of financial markets can show that when objective values are at stake, such as the good name of single markets, the trust in a free trade economy and the safety of private savings, the English legislature did no longer rely on onesided regulation. It deeply changed self-regulatory models with the purpose of making public regulatory powers prevail.

17. See John Kay \& John Vickers, Regulatory Reform: An Appraisal, in DeREGUlATION OR 
Therefore, the achievement of the common good depends on whenever it, by chance, happens to correspond with private interests.

In a different model, the State entrusts meaningful social tasks to a private body while continuing to regulate the overall legal structure and decision-making process. ${ }^{18}$ Without maintaining ultimate authority, there would be no guarantees that the task entrusted to the private body would be successfully fulfilled. In such a case, self-regulation becomes an instrument in the hands of public entities where the involved private body is nothing more than an expression of indirect administration. ${ }^{19}$ Despite that, an exchange is nevertheless realized between the private stakeholders and the State; the private stakeholders relinquish in whole, or in part, their regulating and managing autonomy while the State vests in the private stakeholders the total, or partial, enforcing power typically granted by the law.

The question then becomes, what model of regulation would be better suited for the internet: a self-regulating one independent from the law or a self-regulation model shaped by binding law that functions as part of the legal system?

An answer cannot be wholly in favour of self regulation or binding law, but should be found in an intermediate position. US scholars, ${ }^{20}$ mainly Lessig, ${ }^{21}$ have looked for a solution to the regulation issue in four constraints: "the law, social norms, the market and architecture". A good example of how these constraints should mix is shown by the evo-

RE-REgulation?: REgulatoRy REFORM IN EUROPE AND THE UNited StATES 239 (Giandomenico Majone ed., 1990), ("[Private bodies] "may claim that their objectives are in line with the public interest, but whether or not this is so will depend on the frameworks in which they operate.").

18. BALDWIN \& CAVE, supra note 14, at 125-126.

19. Sometimes there might be a definitional rather than substantial difference. For instance, the Italian legal tradition typically refers to a concept of "indirect administration" which comes close to the concourse among the binding sources and self-regulation set forth by Anthony Ogus in his article, Rethinking Self-Regulation. The author clearly explains the role of the State: to promote the competition between the S.R.A. and "lay down a minimum quality standards which the S.R.A. regimes must presumptively satisfy" Rethinking Self-Regulation, supra note 12, at 106.

20. See, e.g., Charles D. Raab \& Paul De Hert, Tools for Technology Regulation: Seeking Analytical Approaches Beyond Lessig and Hood, in REGULATING TECHNOLOGIES: LEGAL FUTURES, REGULATORY FRAMES AND TECHNOLOGICAL FIXES 236 (Roger Brownsword \& Karen Yeung eds., 2008); Julie E. Cohen, Cyberspace as/and Space, 107 COLUM. L. REV. 216 (2007); JONATHAN ZiTTRAin, THE FutURE OF THE INTERNET AND How TO STOP IT 125-26 (2008); ANDREW MuRRAy, INFORMATION TECHNOLOGY LAW: THE LAW AND SOCIETY 62-66 (2010) [hereinafter MURRAY, INFORMATION TECHNOLOGY LAW].

21. LAWRENCE LeSSIG, CODE: VerSiON 2.0 122-32 (2006) [hereinafter CODE: Version 2.0]. 
lution of piracy in the Internet. Here two values face each other: the copyright holder's right to an adequate revenue, and the right of Internet users to freely access websites. ${ }^{22}$ Criminal sanctions alone proved to be largely ineffective, because the illegal download from Internet was not considered socially reprehensible. ${ }^{23}$ A turnabout occurred with policies of substantial price reductions for legal purchases, also due to the introduction of creative commons licensing, ${ }^{24}$ to the construction of which scholars gave an essential support. ${ }^{25}$ Creative Commons offers copyright holders a simple way to mark their creative works with the freedoms they intend for it to carry: "[t]hat mark is a license which reserves to the author some rights, while dedicating to the public rights that otherwise would have been held privately. As these licenses are nonexclusive and public, they too effectively build a commons of creative resources that anyone can build upon." 26 The final outcome was that Internet users deemed that paying a reasonably low price for legal purchases was more convenient than facing the possibility of heavy criminal sanctions.

Creative Commons contributed greatly in preventing criminal behavior since they helped educate the community of web surfers to be lawful by offering them a chance to have their way at a low cost.

In modern societies pluralism is a basic principle, not by chance a cornerstone of the regulatory issue in the Internet. This principle is construed here in the terms of different sources of law, both public and private, concurring in the regulation. But pluralism must be measured against the necessity of a legal system, ${ }^{27}$ i.e. a coherent and comprehensive set of rules. The compatibility is generally assured in European Civil Law countries through the notion that the sources of law are placed in a hierarchical order ${ }^{28}$ specified at a constitutional level. But

22. See LAwrence LeSsig, Free CUlture 78 (2004), available at http://www.freeculture.cc/freeculture.pdf ("we should be securing income to artists while we allow the market to secure the most efficient way to promote and distribute content .... [T] hese changes should be designed to balance the protection of the law against the strong public interest that innovation continue.") [hereinafter FREE CULTURE].

23. MURRAY, INFORMATION TECHNOLOGY LAW, supra note 19, at 62-64.

24. Christopher T. MARSDEN, INTERNET CO-REgulation: EuROPEAN LAW, Regulatory GOVERnANCE AND LegitimaCy IN CybersPaCe 90-91 (2011); See generally Mike Godwin, Cyber Rights: Defending Free Speech in the Digital Age 186-254 (The MIT PRESS 2003).

25. Lawrence Lessig, Creative Commons @ 5 Years, CREATIVE Commons (Oct. 1, 2007), http://creativecommons.org/weblog/entry/7693 [hereinafter Creative Commons].

26. LESSIG, CODE, supra note 18, at 199.

27. See, for all, the classic contribution by SANTI RomAnO, L'ORDINAMENTO GIURIDICO (The Legal System), Sansoni, Firenze, III ed. 1977 (first published in 1918), spec. chap. I.

28. See Federico Sorrentino, Le fonti del diritto italiano (The sources of the Italian 
also the American experience should be read as posing a precise order between heteronomy and private law. ${ }^{29}$ The latter may integrate the political decision-making initiated by the former, but is not allowed to totally take its place and initiate that decision-making by itself. ${ }^{30}$

A question arises here about which role should be reserved to the State.

It should not be called to act as a regulator in detail of individual behaviour, but rather as an overall system architect, intervening before and after self-regulation. Ex ante, the State will define the general rules, the goals to be pursued, the values to be fulfilled. Ex post, it will be in the State's responsibility to correct any deviation of private regulations from the rules it has preliminarily set.

More specifically, the relative weight of heteronomy upon selfregulation will grow together with the capacity of the negotiated law to seek erga-omnes effects extending its application to a wider community than the one which it directly represents, ${ }^{31}$ In such a case it will fall upon the State to look into the structure and the organization of the private subjects in order that an adequate representativeness, transparency, and democratic decision-making processes may be insured. ${ }^{32}$ The necessity for the State to intervene is given by the substantial equivalence between private regulation and a properly legal source of law.

Conclusively, in a correct order, law comes first, self-regulation follows. If the order is inverted, the inherently secondary nature of selfregulation with respect to the law will be merely fictitious. ${ }^{33}$ Selfregulation will absorb a substantial law-making role and will be applied as a fully legal source of law. Damages to the constitutional architecture will be inevitable.

Nevertheless, it may happen that the correct relationship between

Law), Cedam, Padova, II ed., 2015, pp, 31-32.

29. See generally W. Cesarini Sforza \& Salvatore Romano, Il Diritto Dei Privati [The Law of Privates], in 5 Civiltà DEL DiRITTO [Civilization OF LAW] (1963).

30. See generally De Minico, A Hard Look, supra note 13, at 197-200 (discussing the relationship between binding and consensual law).

31. Black, supra note 6 , at 30,32. With specific reference to the Internet, see Jonathan Cave, Policy and regulatory requirements for a future Internet, IN RESEARCH HANDBOOK ON GOVERNANCE OF THE INTERNET 161 (2013).

32. Rolf H. Weber et AL., Shaping InTERnet Governance: Regulatory Challenges 105 (2009); see also, JaCk Goldsmith \& Tim Wu, Who Controls the INTERNET? ILLUSIONS OF A BORDERLESS WORLD 17 (2006).

33. A detailed analysis may be found in a previous work of mine - GiOvANNA DE MinICO, REGOLE. COMANDO E CONSENSO 125 (2005) (It.). Chapter four of that book is dedicated entirely to this issue. 
heteronomy and self-regulation be subverted. ${ }^{34}$ France came close to it during Sarkozy's term in office ${ }^{35}$ due to the President's belief that selfregulation would be the cure for all the ills of the Internet. ${ }^{36}$ If in following such a myth a full control of the internet should be vested upon private interest governments, ${ }^{37}$ a corporativistic involution of the net would inevitably ensue. The rules would be shaped in close accordance with those private economic interests.

A reference to net neutrality ${ }^{38}$ is also in order. A conflict is under way between two competing rights. On one hand, the right of Broadband providers to sell the access to the Internet at different prices; on the other, the consumers' right to choose services, devices, applications and contents in accordance of their taste and regardless of connection speed. This is the basic playground of what is generally defined as net neutrality, and offers a good test for the relationship between heteronomy and self regulation.

In the U.S.A the conflict has fostered two different answers. The first one entrusts a public body, i.e. the Federal Communication Commission (hereinafter F.C.C.), ${ }^{39}$ with a light regulation requiring broadband providers not to block access, degrade, or favor any legal content, applications, services, or non-harmful devices over others. The second one remits to the negotiations between the broadband provider and the

\footnotetext{
34. See MARSDEN, supra note 24, at 58.

35. See, N. Sarkozy, Opening of the eG8 Forum: Address by Nicolas Sarkozy, President of the French Republic, May 24, 2011, Paris, at http://www.g8.utoronto.ca/summit/2011deauvilleleg8/eg8-sarkozy-en.html.

Among newspapers' articles, see: K.WILLSHER, Sarkozy opens 'historic' forum on future of internet in runup to G8, at http://www.theguardian.com/technology/2011/may/24/sarkozy-opens-eg8-summit; E.P Fannermay, G-8 Leaders to Call for Tighter Internet Regulation, 24, 2011, at http://www.nytimes.com/2011/05/25/technology/25tech.html?_r=1

36. For contrasting approaches by the U.S. and France, see G8 Summit, Deauville G8 Declaration Renewed Commitment for Freedom and Democracy (May 26-27, 2011), available at http://www.whitehouse.gov/sites/default/files/uploads/deauville_declaration_final_-_eng_8h.pdf.

37. See Wolfgang Streeck \& Philippe C. Schmitter, Community, market, state - and associations? The prospective contribution of interest governance to social order, in PRIVATE INTEREST GOVERNMENT BEYOND MARKET AND STATE 16 (Wolfgang Streeck and Philippe C. Schmitter eds., 1985).

38. A clear and comprehensive definition of the net neutrality was given by the Federal Communication Commission. See Preserving the Open Internet Broadband Industry Practices, 25 FCC Rcd. 17905, 17906 (2010), available at https://apps.fcc.gov/edocs_public/attachmatch/FCC10-201A1_Rcd.pdf [hereinafter Preserving the Open Internet]. For a recent synthesis, see KENNETH C. CREECH, ElECTRONIC MEDIA LAW AND REGULATION 351(Routledge 6th ed. 2014).

39. See Federal Communications Commission, REPORT AND ORDER. ACT TO PRESERVE INTERNET FREEDOM AND OPENNESS, http://hraunfoss.fcc.gov/edocs_public/attachmatch/FCC-10201A1_Rcd.pdf; The Dissenting Statement of Commissioner Robert M. McDowell may be found at http://transition.fcc.gov/Daily_Releases/Daily_Business/2012/db0822/FCC-12-92A3.pdf.
} 
content provider the quality and speed of the connection. In such a case, the negotiation is incompatible with the consumer's right to a free choice, and therefore, a right to the net in a strict sense does not exist anymore.

On the question of what net neutrality should be, the FCC has repeatedly spoken on, and has recently launched, a rulemaking procedure on how best an open Internet can be protected and promoted. ${ }^{40}$ The opening question was: "[w]hat is the right public policy to ensure that the Internet remains open?" Two options were set forth. The first one was to maintain the existing regulatory approach. Under the second one, the cable and phone companies would be required to provide a basic and equal level of unfettered Internet service to their broadband subscribers, beyond which they would be allowed to charge different fees for a faster delivery to consumers. It was objected that the second option allowing the distinction between basic and premium offerings would have divided the Internet into the "haves" and the "have-nots".

The first solution has finally prevailed ${ }^{41}$ : a really open Internet governed by public rules resistant to the economic interests of broadband providers. However, this querelle should be considered still open. ${ }^{4}$

The examples made so far show a self-regulation secondary to binding law. But they also show a pluralistic environment of which selfregulation is a necessary element. Teubner's theory ${ }^{43}$ on porous law may be recalled here. The basic assumption is that the State is unable to keep

\footnotetext{
40. See FCC Launches Broad Rulemaking on How Best to Protect AND Promote THE OPEN INTERNET, FCC (May 15, 2014), available at http://www.fcc.gov/document/protecting-and-promoting-open-internet-nprm.

We can note that the Obama Administration took a cautious stand to this conflict. Haley Sweetland Edwards, Obama Backs Away From Net Neutrality Campaign Promises After FCC Vote, TIME (May 15, 2014), http://time.com/101794/obama-backs-away-from-net-neutrality-campaignpromises-after-fcc-vote/.

41. See Federal Communications Commission, STRONG, SUSTAINABLE RULES TO PROTECT THE OPEN INTERNET, February 26, 2015, at http://www.arentfox.com/sites/default/files/DOC-302200A1.pdf

42. The FCC decision was taken with a narrow three-two majority and the opposing commissioners made it clear they would keep fighting against the decision.

With regards to the matter see: Rudy Takala, Seven Lawsuits Now Pending Against FCC Over 'Net Neutrality' Rule, at http://www.cnsnews.com/news/article/rudy-takala/seven-lawsuits-nowpending-against-fcc-over-net-neutrality-rule; JOSH TAYLOR, Net neutrality decision 'monumentally flawed': FCC commissioner, at http://www.zdnet.com/article/net-neutrality-decisionmonumentally-flawed-fcc-commissioner/.

43. See Gunther Teubner et AL., LAw AS An Autopoietic System 100, 139-140 (Ruth Adler trans., 1993).
} 
an effective monopoly of lawmaking. It therefore acknowledges its own limitations, allowing other subjects ${ }^{44}$ the power to write rules for individual and collective behaviors which are subsequently taken up as part of the legal system. This is the theory of reflexive law, which correctly describes the experience of modern legal systems, although attention must be paid to avoiding some possible excesses. ${ }^{45}$ Reflexive law finds an appropriate structural solution in a pluralistic architecture in which a higher-level legal system - the State - encompasses one or more autonomous legal subsystems, which exist and operate within the limits established by the former. ${ }^{46}$ In this perspective the subsystems are necessarily secondary to the higher-level legal system, and the role of private subjects may be differently defined as far as scope, procedures, effects are concerned. A French author has depicted the private contribution as limited to the "mise en oeuvre des politiques publiques" (the implementation of public policies). ${ }^{47}$ In any case, the State maintains a full authority ${ }^{48}$ and a final word on the system as a whole, although relinquishing the role of exclusive lawmaker,

The circle is now complete: political decision-makers and public powers should keep their leadership in the self-regulating processes, intervening with ex ante determination of its goals, and ex-post control and correction.

A measure of heteronomous regulation is necessary. But a question is open: which should the scope and content of this regulation be?

As far as the Internet is concerned, the starting point is found in the

44. See A Hard Look, supra note 15, at 198 ("Hence, private associations must promote policies adjusting self-regulation from the beginning to social purposes . . . and the State claims "the chance of political decision' though respecting 'the organised power to act of social bodies.").

45. See Gunther Teubner, Substantive and Reflexive Elements in Modern Law, 17 LAW \& SOC'Y REV. 239, 278 (1982-1983) [hereinafter Substantive and Reflexive Elements in Modern Law]; see generally GunTHER TEubNER \& Alberto FebBrajo, STATE, LAW, AND ECONOMY AS Autopoietic Systems, (Dott. A. Giuffré ed., 1992); see also GunTHER TeubNER, DilemMas of LAW IN THE Welfare STATE, (Walter de Gruyter ed., 1986); and see ReNATE MAYNYZ, STEUERUNG, STEUERUNGSAKTEURE UND STEUERENGSINSTRUMENTE: ZUR PRÄZISIERUNG DES PROBleMS (CONTROL, CONTROL ACTORS AND STEUERENGSINSTRUMENTE: TO CLARIFY THE PROBLEMS) 24, 70 (1986).

46. Walter L. Bühl, Grenzen der Autopoiesis [Limits of autopoeiesis], in 39 KöLNER ZEITSCHRIFT FÜR SOZIOLOGIE UND SOZIALPSYCHOLOGIE 247 (1987).

47. Charles-Albert Morand, La contractualisation corporatiste de la formation et de la mise en oeuvre du droit [The corporatist contracting training and implementation of the law], in L'ETAT PROPulsif. CONTRIBUTION À L'ETUde DESINSTRUMENTS D'ACTION D'ETAT [STATE Propulsion CONTRIBUtion to THE STUdy InSTRUMENTS ACTION STATE] 207 (Charles Albert ed., 1991).

48. The Regulation OF CyberspaCe, supra note 3, at 250-251. 
Courts' decisions - both the European Court of Human Rights ${ }^{49}$ and the U.S. Supreme Court ${ }^{50}$ - affirming that rules should be specifically suited to their object. Therefore, offline media regulations cannot as such be made applicable online. ${ }^{51}$ Should this happen, the Internet would lose its uniqueness. Furthermore, an unfettered Internet is essential to the circulation of ideas which is a basic instrument of economic and social growth. ${ }^{52}$ As a consequence, regulations should be kept at a minimum level.

Regulation of the Internet is thus faced with the supreme value of the marketplace of ideas ${ }^{53}$ resembling a transposition of the economic theory of laissez-faire on the ground of an exchange of immaterial goods. Freedom of speech imposes itself as the unique and real cornerstone of democracy. As a result, it is reasonable to assume that "governmental regulation of the content of speech is more likely to interfere with the free exchange of ideas than to encourage it." ${ }^{54}$ As the Supreme Court stated in the ACLU the assumption that in a democratic society censorship may prove beneficial is "theoretical but unproven.",55

For the first time in the history of mankind, billions of people can easily communicate and share information through the Internet, and there can be no overwhelming public or private interest justifying the substantial curtailment of the Internet's effectiveness. Therefore, a basic principle can be drawn stating that a regulation of the Internet, even when required should be kept as light and unobtrusive as possible.

49. Animal Defenders Int. v. United Kingdom, App. No. 48876/08, Eur. Ct. H.R. (2013) (forthcoming in European Human Rights Review).

50. Reno v. American Civil Liberties Union, 521 U.S. 844 (1997).

51. The United State Supreme Court has recognized that the "differences in the characteristics of new media justify differences in the First Amendment standards applied to them." Associates \& Aldrich Co. v. Times Mirror Co., 440 F.2d 133, 135-36 (9th Cir. 1971) (citation omitted); see, e.g., Red Lion Broad. Co. v. FCC, 395 U.S. 367 (1969); Se. Promotions, Ltd. v. Conrad, 420 U.S. 546, 557 (1975); FCC v. Pacifica Found., 438 U.S. 726 (1978); Turner Broad. Sys. Inc. v. FCC, 512 U.S. 622, 637-38 (1994); Sable Commc'ns of Cal., Inc. v. FCC, 492 U.S. 115, 128 (1989).

52. See Special Rapporteur on the promotion and protection of the right to freedom of opinion and expression, Human Rights Council, U.N. Doc. A/HRC/23/40 (Apr. 17, 2013) (Frank La Rue), available http://www.ohchr.org/Documents/HRBodies/HRCouncil/RegularSession/Session23/A.HRC.23.4 0_EN.pdf, in which the author exposes serious concerns for the practices adopted by many States aimed at keeping the Internet under close surveillance and control.

53. Abrams v. United States, 250 U.S. 616, 630 (1919) (Wendell, J., dissenting).

54. Reno, 521 U.S. at 885.

55. Id. 


\section{WHY SHOULD THE CONSTITUTIONALIZATION OF THE INTERNET BE NECESSARY?}

With a general framework for the internet drawn up, one question remains: is it then necessary to update those national Constitutions that do not mention the Internet at all?

As a starting point, three Constitutions - namely the Italian, French and American ones - will be discussed, as they already entail norms protecting traditional media - radio, television, and newspapers - yet at the same time lack specific rules for online media such as Internet blogs and social network websites. ${ }^{56}$

More specifically, in the Italian Constitution art. 15 (freedom of communication) and art. 21 (freedom of speech) ${ }^{57}$ do not refer to the Internet at all. This is easily explained considering that the constitutional formulas have remained unchanged since 1948. Recently, there has been considerable debate among scholars about the necessity of introducing new ad hoc provisions ${ }^{58}$ through a constitutional reform.

It can be argued against the thesis of a formal revision that any new formula would be focused on the existing technology, and could not easily cover the inevitable and unforeseeable future developments.

This would expose any constitutional innovation to the risk of premature obsolescence: a detailed provision might be useful today, but useless, or even harmful, tomorrow. It should be further noted that the

56. Only two Constitutions dealt with new media through explicit provisions, see 2008 SyNTAGMa [SYN.][CONSTITUTION] 5a, co.2 (Greece) and CONSTITUCION DE REPÚBLICA DEL ECUADOR [C.R] art. 16.

57. See Art. 15 Constituzione [Cost.] (It.) ("Freedom and confidentiality of correspondence and of every other form of communication is inviolable. Limitations may only be imposed by judicial decision stating the reasons and in accordance with the guarantees provided by the law."). Article 21, the only article relevant here, states: "Anyone has the right to freely express their thoughts in speech, writing, or any other form of communication." Id. art. 21.

58. Concerning the previous Leg. XVI, see the "disegno di legge costituzionale, A.S. n. 2475, 6/12/2010, at http://www.senato.it/leg/16/BGT/Schede/Ddliter/36202.htm [hereinafter Project of constitutional law 2475/2010]. Among scholars, see Stefano Rodotà, Il mondo della rete. Quali diritti e quali vincoli [THE WORLD IN THE NET. WHAT RIGHTS AND WHAT CONSTRAINTS] (2014).

Concerning the current Leg. XVII, see the "disegno di legge costituzionale, A.S. 1317, 17/2/2014, at http://www.senato.it/leg/17/BGT/Schede/Ddliter/43981.htm [hereinafter Project of constitutional law 1317/2014] and also the "disegno di legge costituzionale, A.S. 1561, 10/7/2014, at http://www.senato.it/leg/17/BGT/Schede/Ddliter/44665.htm [hereinafter Project of constitutional law 1561/2014]. In doctrine see: O.Pollicino, 'Esame in sede referente dei DDL 1317 e 1561 (diritto di accesso ad Internet)', at http://www.medialaws.eu/esame-in-sede-referente-dei-ddl1317-e-1561-diritto-di-accesso-ad-internet/ and G. De Minico, 'A proposito dei disegni di legge di revisione costituzionale, A.S. 1561 e 1317, I Commissione del Senato, Leg. XVII, 10/3/2015' (forthcoming). 
real focus of Internet regulation is found - as it will be explained more extensively later - in the identification of a supranational rule-maker. A national Constitution, applicable within the territory of a single State, might be an obstacle in the broader perspective of a discipline that encompasses a number of States with different legislative histories, experiences, and economic and social interests. From this point of view, a specific and detailed constitutional provision might not be the right answer.

An alternative is found in adopting a broad interpretation of the existing constitutional provision, in order that they may be applied to the new virtual reality. ${ }^{5}$

This approach would be made easier by the inherent flexibility of many Constitutional provisions. ${ }^{60}$ This is the case of art. 15 and 21 of the Italian Constitution, which grant protection to named media, but also refer respectively to "every other form of communication" (Art. 15) and "any other means of communication" (Art. 21). ${ }^{61}$

A similar example is given by the First Amendment of the U.S. Constitution, ${ }^{62}$ which has been construed in the sense that the Internet is fully within the constitutional safeguards of the freedom of speech. ${ }^{63}$ No reform of the Amendment has been deemed necessary.

The extension of the same constitutional protection to rights and liberties offline and online does not imply an automatic transfer of the offline discipline, as a whole, in the world of virtual reality. As it has been argued previously, this would not be effective and would only undermine the uniqueness of the Internet. The extension considered here is limited to the basic constitutional guarantees of rights and liberties, while a different sub-constitutional regulation may remain to be provid-

59. See Laurence H. Tribe, The Constitution in Cyberspace: Law and Liberty Beyond the Electronic Frontier, Electronic Privacy Information Center (1991), at http://epic.org/free_speech/tribe.html.

60. On the issue of the flexible structure of many Constitutional provisions see GIUSTIZIA CONSTitUZiOnALE 246 (Gustavo Zagrebelsky \& Valeria Marceno eds., 2012).

61. Arts. 15, 21 Constituzione [Cost.] (It.). This is a typical example of a flexible provision. The interpreter should be able to read it as encompassing new forms or means of communication previously unheard of, made available by technological innovation. This text remains unchanged while staying adherent to new conditions.

62. Among the first on the elasticity of the text and the discretionary power, Justice Harlan stated, "I do not see why Congress should not be able as well to exercise its 'discretion' by enacting statutes so as in effect to dilute equal protection and due process decisions of this Court." Katzenbach v. Morgan, 384 U.S. 641, 669 (1966); see also JONATHAN D. VARAT ET AL., CONSTITUTIONAL LAW: CASES AND MATERIALS 1184 (1997).

63. See supra note 51. 
ed in detail. This point will be made clear by a closer look at the Italian and U.S. Constitutions, with different specific provisions but, similar problems posed by the new virtual reality.

\section{A. From the "law clause" to the "rule of law" of the international system}

I shall start by examining the basic safeguards provided by the Italian Constitution for fundamental rights and liberties offline.

In the Italian Constitution a basic guarantee of rights and liberties is found in the law clause ("riserva di legge"), ${ }^{64}$ by which a primary legislative rule must be adopted first, ${ }^{65}$ while a secondary rule may be adopted subsequently and only within limits necessarily defined by the former. ${ }^{66}$ In matters concerning copyright and the Internet, Legislative Decree n. $44 / 2010^{67}$ does not comply with this principle, vesting upon the Authority for the Guarantee of Communication, ${ }^{68}$ a general responsibility, without defining in detail the Authority's powers. In the absence of a specific legislative foundation, the Authority itself (Deliberation N. 680/13/CONS) ${ }^{69}$ has assumed to have the power of closing websites or requiring that some contents be cancelled, following a summary assessment of their illicit nature .The Authority's decision is a secondary source, and therefore in virtue of the "law clause" is not allowed to introduce an original innovation in the legal system without an adequate foundation in a primary source. ${ }^{70}$ Consequently, the compli-

64. G. ZAGREBELSKY, Il sistema costituzionale delle fonti del diritto, (The constitutional system of the law sources) (Torino: Giappichelli, 1984) 84-87; also L. Carlassare, I regolamenti dell'Esecutivo e principio di legalità [The rules of the Government and the legality principle] (Padova: Cedam, 1966) 223; E. Cheli, Potere regolamentare e struttura costituzionale [Regulation power and Constitutional structure] (Milano: Giuffrè, 1977) 50

65. A primary source is construed by the Italian doctrine as a regulatory will expressed by a constitutional power specifically vested with political functions. This source has the basic task to define and initiate the policy project that will be developed by the secondary sources (see for all the clear pages written by V. CRISAFULLI, Lezioni di diritto costituzionale (Lessons of constitutional law), $2^{\text {nd }}$ vol., (Padova: Cedam, 1993), 140-159.

66. Because of this secondary nature, some scholars have stated that in force of the legality principle, a previous provision of law conferring a blank power to the secondary source is not sufficient. The law must intervene indicating the aim, the scope, and the guidelines with which the secondary power is required to comply. So G.U. Rescigno, 'Sul principio di legalita' [Around the legality principle]19 (1995) Dir. Pubbl., pp. 264-265.

67. Decreto Legislativo 15 marzo 2010, n. 44, in G.U. 29 marzo 2010, n. 73 (It.)

68. From now on: A.G.Com.

69. Delibera N. 680/13/CONS [Deliberation $n$. 680/13/CONS], at http://www.agcom.it/default.aspx?DocID=12228

70. G. De Minico, 'Indipendenza delle autorità o indipendenza dei regolamenti? Lettura in parallelo all'esperienza comunitaria' (Independence of the Authorities or independence of the 
ance with the law clause and the hierarchy principle of both the Legislative Decree 44/2010 and the Authority's Deliberation may be questioned.

The Italian case may recall the French law Hadopi $1,{ }^{71}$ by which a decision-making power upon websites is given to an independent authority. ${ }^{72}$-In a comparative context, a safeguard for the protection of human rights substantially equivalent but not identical to the Italian Constitution's "law clause" means that the discipline of fundamental rights must be prescribed by a law that is "adequately accessible", and "formulated with sufficient precision to enable the citizen to regulate his conduct." ny reveals a notable difference between the international principle and the Italian clause. In the perspective of the "rule of law", the secondary sources are usually allowed a much wider access to regulation. ${ }^{77}$ Not on-

regulations? A comparative reading with the European experience), in M. D'Amico e B. Randazzo (eds), Alle frontiere del diritto costituzionale (At the borders of constitutional law. Works in honour of Valerio Onida (Milan: Giuffré, 2011) 731-733.

71. La Protection Pénale de la Propriété Littéraire et Artistique sur Internet [The Criminal Protection of Literary and Artistic Property on the Internet]JOURNAL OFFICIEL DE LA RÉPUblique FranCAISE [J.O.] [OFFICIAL GAZETTE OF FrANCE], Oct. 28, 2009, p. 18290, avialable http://www.legifrance.gouv.fr/affichTexte.do?cidTexte=JORFTEXT000021208046\&categorieLie $\mathrm{n}=\mathrm{id}$.

72. In the case under examination, the conflict arises between the copyright - the author's right to his intellectual property - and everyone's right to be informed. Clearly unequal values are compared: one financial, and the other, a fundamental right. The latter, which would not be comparable with a value of a different nature in principle, is de facto widely sacrificed by both the French and Italian laws in favor of the right to an economic exploitation of intellectual work. Another flaw can be found considering that in this case, the measure of coexistence between conflicting values is a basic political issue. Therefore, it cannot be wholly entrusted to an authority, Court or I.R.A., and should be vested primarily upon a representative and politically responsible legislator.

73. See for examples of law clause the First Part ( Parte I), First Title ( Titolo I) of the Italian Constitution for the examples of the law clause.

74. The literature concerning the "rule of law" is unlimited. For present comparative purposes it is sufficient to refer to scholarly contributions based on recent case law developments; see, among others, FEDERICO FABBRINI, FUNDAMENTAL RightS IN EUROPE: CHALLENGES AND Transformations in COMPARATIVE PERSPECTIVE (1st ed. 2014); DAMIAN CHALMERS ET AL., EUROPEAN UNION LAW: CASES AND MATERIALS 256-58 (3d ed. 2014); DAVID HARRIS ET AL., LAW OF THE EUROPEAN CONVENTION ON HUMAN RIGHTS 345-349 (2009). While for the specific sector of the media freedom see: Helen Fenwick \& Gavin Phillipson, Media Freedom UNDER THE HUMAN RIGHTS ACT 37-311 (2006).

75. Silver v. United Kingdom, 5 Eur H.R. Rep. 372 (II 87) (1980).

76. Sunday Times v. United Kingdom, 2 Eur. H.R. Rep. 245, 271 (II 49) (1980).

77. Well said by David Harris, Michael O'Boyle, \& Edward Bates in LAW OF THE EUROPEAN CONVENTION ON HUMAN RIGHTS 344 (2d ed.2009): "the rule need not be a rule of domestic law but may be a rule of international law or Community law so long as it purports to 
ly are the Assembly's legislative acts allowed to intervene, but the decisions from the public authority (containing general and abstract provisions) are permitted to as well. ${ }^{78}$

The rule of law can therefore be summarized as upholding fundamental rights against the public powers' arbitrary decisions ${ }^{79}$ in spite of its legal form, be it an act issued by the Parliament or by the Government. ${ }^{80}$ This principle strengthens the protection of rights, namely in preventing the violation of liberties that may arise from a Parliamentary act, which does not comply with the standards of generality and abstractness. ${ }^{81}$ Conversely, the same principle weakens this protection by allowing a secondary source to set out the discipline without any previous legislative intervention.

\section{B. From the "jurisdictional clause" to the due process}

Fundamental rights and liberties online can find within the Italian Constitution a second basic safeguard in the jurisdictional clause ("riserva di giurisdizione", as explained elsewhere). This "riserva", applying the principle of separation of powers, ${ }^{82}$ entrust the power of judicial review solely upon the judiciary.

The Italian Constitution provides a strong protection for the independence of the judiciary. No political or administrative body is allowed to interfere with judicial functions, ${ }^{83}$ which must be carried on by exclu-

authorize the interference. It may consist of a whole legal regime regulating the area of activity, including rules made by a delegated rule-making authority (Barthold $v$ FRG A90 (1985); 7 EHRR 383 pagas 45-6 (1985) and rules from more than one legal order." See also DANIEL MOECKLI ET AL., INTERNATIONAL HUMAN RigHTS LAW 111 (2010).

78. Silver, 5 Eur H.R. Rep. at 372. Sunday Times v. United Kingdom, 2 Eur. H.R. Rep. 271(II 47) (1979). For further doctrine examples, See HelEN FENWICK \& GAVIN PHILLIPSON, MEDIA FREEDOM UNDER THE HUMAN RIGHTS ACT 47 (2006).

79. Kruslin v. France (1990) 1 EHRR 562, para. 30.

80. See Draft charter of Fundamental Rights of the European Union, Brussel, 8 March 2000 (13.03), a preview of what will then become Art. 53 of the Charter: «According to the European Conventions of Human Rights, the term 'law' must be understood in the material not the formal sense. It can cover sub-legislative, customary or case of law standard».

81. See generally Robert S. Summers, A Formal Theory of the Rule of Law, RATIO JURIS (1993).

82. For the purpose of this essay, a general definition of the principle of separation of powers will be adequate: a more or less rigid division of power between the Legislative, the Executive and the Judiciary aimed at the essential checks and balances required by democracy. For a supranational analysis beyond specific States, see CHRISTOPH MOELLERS, THE THREE BRANCHES: A COMPARATIVE MODEL OF SEPARATION OF POWERS 150 (2013).

83. On the guaranteed independence of the judiciary power see, among the others: R. Guastini, 'Commento all'art. 101', at G. Branca-A. Pizzorusso (eds), Commentario della Costituzione. La magistratura, vol. Ist, (Bologna-Roma, 1994) 172; F. Bartole, Autonomia e indipendenza 
sively applying the law. This independence is the basic reason why only a judge is allowed to limit fundamental rights and liberties in compliance with the law. One can see here that the jurisdictional clause and the law clause work in synergy.

For this reason, a strong dissent should be expressed against ${ }^{84}$ the Italian Legislative Decree n. 44/2010.

The constitutionality of the Decree can be challenged on several grounds, one of which is found in the lack of compliance with the jurisdictional clause. The power to "clean" the websites, ordering that a specific content be cancelled, is entrusted to an independent regulatory authority. Since such an order inevitably affects the freedom of speech, a constitutionally sound solution would require a court proceeding and a judicial decision. The Decree's provision may recall the French law Hadopi 1, before the decision of the Conseil Constitutionnel and the subsequent modifications.

On an international level, the jurisdictional clause is present. In the European Court of Human Rights' decisions, for instance, it is in the weaker form of due process. ${ }^{85}$ In fact the European Convention on $\mathrm{Hu}-$ man Rights (especially, Articles. 5-6) does not force EU Member States to confer power, as detailed above, only to a judge. ${ }^{86}$ Different authori-

dell'ordine giudiziario (Padova: Cedam 1964); C. Mezzanotte, 'Sulla nozione d'indipendenza del giudice', at B. Caravita di Toritto (ed), Magistratura, CSM e principi costituzionali (Bari: Laterza 1994); A. Pizzorusso, 'La Corte costituzionale ed il principio di indipendenza del giudice', at Scritti su la giustizia costituzionale in onore di Vezio Crisafulli (Padova: Cedam, 1985).

84. Giovanna De Minico, Libertà e copyright nella Costituzione e nel Diritto dell'Unione (January 2014) [Fundamental Rights and Copyright in Italian Constitution and in the European System], available at http://www.associazionedeicostituzionalisti.it/articolorivista/libert-ecopyright-nella-costituzione-e-nel-diritto-dell-unione (last visited Mar. 4, 2015) [hereinafter De Minico, Fundamental Rights and Copyright].

For a sharp critique, see M. Avvisati, 'Diritto d'autore in rete e Costituzione: concerto tra le fonti?', 3 (2014) at http://www.osservatoriosullefonti.it/component/docman/cat_view/199-note-ecommenti.

Pending the publication of this essay, the Decree was challenged on the grounds illustrated above before the Constitutional Court, see: Tar Lazio, sez.I n. 10016 /2014 and n.10020/2014, at http://www.neldiritto.it/appgiurisprudenza.asp?id=10792\#.VWYGbc_tmko

85. Being this topic only partially connected to our study it is enough here to refer to the same scholars quoted at note $n$. 87.

86. The concept of "judge" or "tribunal" is interpreted by the E.C.H.R. in an autonomous manner. In fact, in the Ringeisen case (ECHR, 16 July 1971, Ringeisen -Austria (Series A-16), parag. 94-95) the Court had to decide whether article six was applicable in an Austrian dispute concerning the purchase of property. The Court held that the administrative character of the Authority was of little consequence, so it concluded that the body was a "tribunal." In doctrine for all: F. Matscher, 'La notion de 'tribunal' au sens de la Convention européenne des droit de l'homme', in R. Koering-Jouklin, Les nouveaux développements du procès équitable au sens de la Convention européenne des droit de l'homme (Brussels: Bruylant, 1996), 33. 
ties may be entrusted with the implementation of legal rules, provided that their decisions are based upon a fair hearing and a reasonable motivation. ${ }^{87}$

What matters here is that the act concretely imposing limits will be adopted in an adversarial proceeding, allowing those who must bear those limits to have prompt knowledge of them in order to make their opposing arguments heard. And, should the relevant Authority, after the resolution of the conflicting issues, be convinced of the validity and truth of those limits, it will have to make the iter of its decision understandable to all. ${ }^{88}$ Therefore, the interference with the peaceful enjoyment of one's assets is accompanied by procedural guarantees ensuring a reasonable opportunity to make one's case before the competent authorities. ${ }^{89}$

This approach is considered a somewhat weaker one, as independence, impartiality, and neutrality - essential requisites for a fair assessment of the parties' dispute - are, in principle, more fully ensured by judges, although in different ways in different States.

After examining the essential framework of the constitutional protection of rights and liberties in the Italian legal system, as well as in a comparative perspective, it is necessary to state a point: the underlying assumptions may be deemed valid for any legal system. As Fuller points out, laws must comply with some basic requirements, ensuring at least their legitimacy and efficiency. ${ }^{90}$ In this perspective, the existence of a territorial location may not be relevant. It can therefore be argued that the same framework applies to rights and liberties wherever they are exercised. Their nature or scope does not change when they move to the virtual world of the Internet, nor do they become any less fundamental.

87. The ECHR has developed its own substantive requirements for a "tribunal." In particular, the body must have the power of decision; operate on the basis of rules of law and after proceedings conducted in a prescribed manner; determine matters within its competence; motivate its decisions and be independent and impartial. See MARTIN KUIJER, THE BLINDFOLD OF LADY JUSTICE: JUDICIAL INDEPENDENCE AND IMPARTIALITY IN LIGHT OF THE REQUIREMENTS OF ARTICLE 6 ECHR 175 (2004).

88. This is the case of the Independent Administrative Authorities. As I noted in a previous essay, although they do not belong to the judiciary power, they must motivate their decisions in order to allow a judicial review be conducted over them. G. DE MINICO, INDIPENDENZA DELLE AUTORITA O INDIPENDENZA DEI REGOLAMENTI? LETTURA IN PARALLELO ALL'ESPERIENZA COMUNITARIA' [INDEPENDENCE OF THE AUTHORITIES OR INDEPENDENCE OF THE REGULATIONS? A COMPARATIVE READING WITH THE EUROPEAN EXPERIENCE],731(2011) [hereinafter De Minico, A Comparative Reading].

89. The case law of the Eur. Ct. H.R. is synthesized in the decision of Agosi v. United Kingdom, 9 Eur. Ct. H.R. (ser. A) at 55 (1986).

90. LON L. FULLER, THE MORALITY OF LAW 152-184 (1969). 
The basic function of constitutional safeguards, aimed at preventing any breach of those rights, is equally confirmed. For example, freedom of speech in an online blog should be protected against ex ante controls as it is the case with the written speech of a book. In both cases the speech is addressed to an indefinite number of people and a similar damage would ensue from curtailing a speaker's freedom. Therefore, no rational foundation may be indicated for a different definition or implementation of the constitutional framework.

\section{FROM THE CONSTITUTIONALIZATION OF THE INTERNET TO AN INTERNET BILL OF RIGHTS}

I started my discourse by denying the need for a formal modification of the Constitutions in order to encompass the Internet. Significant similarities can be found in a compared reading of the North American and the European systems. It may now be useful to take a further step in stating the necessity of an "Internet Bill of Rights". 9 "

Regulations of the Internet have so far been discussed through underlining some common elements following a comparative perspective. It is this author's argument that a global and rapidly changing reality shows a highly fragmented picture. More specifically, the mosaic of multiple State net regulations, filtered through widely different social, economic, and political conditions in different territories, cannot effectively keep such a fast pace. Even more, the a-territorial nature of the Internet radically clashes per se with the limitations imposed by State boundaries. $^{92}$ This suggests the increasing necessity of a set of basic rules that can be both generally accepted and acknowledged as a primary, binding source of law for all those public or private subjects interacting with the Internet.

There are a number of fundamental rights and liberties that already enjoy a constitutional protection in different legal systems, even in the absence of specific provisions concerning the Internet. ${ }^{93}$ But undoubtedly the Internet goes nowadays well beyond freedom of speech and communication, crucial as they may be in a democratic society. The In-

91. Lawrence Lessig, Reading the Constitution in Cyberspace, 45 Emory L.J. 3, 7-18 (1996).

92. Allow me to refer to my analysis delivered in one of my books: INTERNET. REGOLA O ANARCHIA, quoted, p. 8.

93. This issue has already been dealt with at the beginning of this essay, where the only two Constitutions, containing explicit provisions for the Internet have been mentioned see supra note 56. 
ternet appears more and more as the most powerful tool ever forged for social inclusion and economic growth, which is exactly why the digital divide should be considered a decisive factor of inequality among countries and individuals. Such a scenario suggests that a conclusive and satisfactory answer cannot be found in the interpretation - broad as it may be-of some constitutional provisions written at a time when there was no awareness of this new reality.

This global situation does indeed urge a proper "Internet Bill of Rights". In doing so, another question is then raised: who is the constituent power of the Internet? In other words: which Authority shall be legitimated $^{94}$ to write the fundamental Charter of the Internet?

It is clear from what I said before that the hypothesis of one or more national States assuming such a role must be rejected. ${ }^{95}$ The aterritorial nature of the Internet would be incompatible with an Authority entrusted with powers constrained within State boundaries. ${ }^{96}$ The features of the Internet require, as stated above, that only a supranational legislator should be called upon to write its Constitution. Even so, one question remains open: should such a legislator be an international body through an authoritative hard-law regulation, or should it rather be the community of Internet 'surfers' through self-regulation? The former have frequently proven to be unable to build the consensus necessary to condense and shape the common good in a supranational synthesis. ${ }^{97}$ Furthermore, they fall easily under the influence of strong national States, the interests of which only occasionally coincide with a broader common good. ${ }^{98}$ In brief, international organizations tend to reproduce, albeit on a smaller scale, the basic flaw of world politics, a system of interactions between autonomous nation-States at best. In this framework,

94. Rudolf W. RiJgersberg, The State of Interdependence. Globalization, Internet and Constitutional Governance 49-68 \& 213-30 (Hague: Asser Press, 2010).

95. See infra

96. CHRIS REED, MAKING LAWS FOR CYBERSPACE 30-34 (2012).

97. See Teubner G., Constitutional Fragments, 66.

98. There is no unanimous definition of the "common good." For example: W. Streeck - P. C. Schmitter, Community, market, state - and associations? The prospective contribution of interest governance to social order, quoted, 16, strongly believes in "the public use of private interest governments [...] which are made subservient to general interests by appropriately designed institutions". On the contrary, C. A. MORAND, La contractualisation corporatiste de la formation et de la mise en oeuvre du droit, in L'ETAT PROPULSIF. CONTRIBUTION A L'ETUDE DES INSTRUMENTS D'ACTION DE L'ETAT 209 (Paris: Publisud, 1991), states that 'L'éclatement de l'intérêt général en une multitude d'intérêts particuliers et sectorialisés remet en cause l'une des justifications fondamentale de l'exercise du pouvoir étatique, son orientation vers la réalisation de l'intérêt public. » 
international organizations have revealed themselves incapable to replace the culture of nation-States with a new one.

Therefore, the idea of an Internet Bill of Right written by its own people, entrusting regulation to an endogenous process of selforganization, might gain some ground. Effective examples can be offered by institutions such as ICANN, ${ }^{99}$ courts of arbitration, or international standardization organizations such as the World Wide Web Consortium. This is a better solution as to the need of effective supranationality. New problems, however, arise, since it refers to a plurality of subjects not yet transformed into a body formally vested with authoritative powers. ${ }^{100}$

Considering the current situation, the risk of a "corporate constitutionalism" cannot be overlooked. ${ }^{101}$ As Teubner stated, such a risk is inherent whenever well-structured and significantly funded private bodies enter the field. ${ }^{102}$ The Internet may very well be the "most prominent case of constitutional law created through multinational corporations private ordering." ${ }^{, 103}$ And even if all stereotypes should be refused, corporate constitutionalism will undoubtedly be accompanied by "the glimmering of the constitution of multi-national enterprises as an autonomous community of entities that have begun to regulate themselves through the construction of systems of governance independent of the states." 104

The risk underlined by Teubner should not be underestimated. A private interest government, to use an expression familiar to some scholars, ${ }^{105}$ is entrusted with social tasks if it enacts regulations affecting not only their associates, but also third parties. This is not the case of a regulatory power bestowed on the decision makers through a contractu-

99. About ICANN governance see: M. Hutter, Global regulation of the Internet domaine name system: five lessons from the ICANN Case, in Karl-Heinz Ladeur (ed), [Innovationsoffene Regulierung des Internet:Neues Recht für Kommunikationsnetzwerke] (Baden-Baden: Nomos, 2003), 39-52.

The French delegation to ICANN's 50th meeting, taking place in London, recently stated that "U.S.-based ICANN is unfit for 'Internet governance"":

100. CASS SunSTEIN, REPUBLIC.COM 69-79 (2001).

101. G. Teubner, Constitutional Fragments: Societal Constitutionalism and GlobaliZATION 56 (Oxford Scholarship Online, 2012).

102. Id.

103. Id.

104. Larry Cata Backer, The Autonomous Global Enterprise: On the Role of Organizational Law Beyond Asset Partitioning and Legal Personality, 41 TULSA L. REV. 541, 567 (2006).

105. See Wolfgang Streeck \& Philippe C. Schmitter, Community, Market, State-and Associations? The Prospective Contribution of Interest Governance to Social Order, 1 EUR. SOC. REV. 119, 127 (1985) available at http://esr.oxfordjournals.org/content/1/2/119.full.pdf. 
al obligation where members involved accept the rules. Instead, were a private interest government to enact and enforce those rules applicable to everyone working in the field beyond the relevant social group of stipulating members, a basic issue of democracy arises. In such cases, the consensus within the social group will not give the regulator an adequate and proper basis to adopt acts affecting third parties per se. The issues of representativeness and democratic governance are paramount, as they ultimately define the interaction among the conflicting interests underlying the rules to be drawn. ${ }^{106}$

Therefore, I propose a median hypothesis. First, the legislative power should be vested in a public supranational authoritative body, based on legal and binding provisions, which also defines the nature and scope of its powers. Second, the decision-making process of such a body should encompass a strong representation of private interests concerning the Internet such as entrepreneurs, web surfers, and consumers. The basic model could be drawn to resemble the notice and comment procedure, well-known to the American experience in the field of regulations. ${ }^{107}$ Opposing stakeholders should discuss basic issues before a public authority, who is able to make the final decision after the different views have been listened to and fully taken into account. The problems of standing and those concerning the choice of interests to be admitted to such a procedure have been extensively explored by the American doctrine, which could be a reference on this point. ${ }^{108}$

The model proposed here would answer the questions on rule maker legitimacy as it would be based on formally legal provisions. It would also offer at least a partial answer to the doubts aroused by the possibility that the supranational body be captured by the interests of the stronger national States participating in its decisions. Such a risk is reduced by the fact that the private competing interests taking part in the decision may formally have a territorial or national identity, but this will not decisively affect their interests or policies.

106. LAURA DeNARdis, The Global WAR FOR InTERNET GOVERNANCE 230 (New HavenLondon: Yale University Press, 2014), focuses on the fact that the multi-stakeholder model isn't good per sé, unless it is based on the democratic values: amongst them, representativeness and equilibrate balance of powers between public and private actors.

107. Administrative Procedure Act, Pub. L. No. 79-404, 60 Stat. 237 (1946).

108. See, e.g., StePhen G. Breyer, ET Al., Administrative LaW AND Regulatory POLICY 869-881 4th ed. 1998); see Martin Shapiro, APA: Past, Present, Future, 72 VA. L. REV. 447 (1986); see also Richard J. Pierce, Jr., Rulemaking and the Administrative Procedure Act, 32 TulSA L.J. 185 (1996); and see Bernard Schwartz, Adjudication and the Administrative Procedure Act, 32 TULSA L.J. 203 (1996). 
The issue of a constituent power for the Internet may currently appear far-fetched, but it is actually something already in agenda, although the attempts to reach a widespread consensus on some basic issues have failed up to now as it has recently happened in Dubai ${ }^{109}$ and São Paulo. ${ }^{110}$

\section{WHAT SHOULD THE ARCHITECTURE OF AN INTERNET BILL OF RIGHTS BE LIKE?}

Although the idea of a supranational constitutional legislator for the Internet may appear unrealistic in the current situation, the need for a set of commonly accepted basic rules is clear and immediately present. Therefore, it is reasonable to assume that a number of States can reach an agreement on those basic rules. Several attempts have been and are being made to this purpose. ${ }^{111}$ Should such an agreement be reached, a set of substantially constitutional rules, binding each State in force of an international treaty, would be laid down. Therefore, an analysis of the contents of an Internet Bill - however formulated and enacted - de-

109. Int'l Telecomm. Union [ITU], Final Acts of the World Conference On International Telecommunications, I.T.U. 37779 (Dec. 3-14, 2012), available at http://www.itu.int/en/wcit12/Documents/final-acts-wcit-12.pdf.

110. Global Multistakeholder Meeting on the Future of Internet Governance, NETmundial Draft Outcome Document Public Consultation: final report on comments, (April 22, 2014), available at http://netmundial.br/wp-content/uploads/2014/04/NETmundialPublicConsultationFinalReport20140421.pdf [hereinafter NETmundial Internet Governance Report].

111. The recent Internet Governance Forum has moved in this direction, but without reaching any results at the moment, Connecting Continents for Enhanced Multistakeholder Internet Governance, Istanbul-Turk., 2-5 September 2014, at http://www.intgovforum.org/cms/igf-2014. Concerning the Italian experience, a recent and most significant development is found in the Draft Declaration of Rights (http://www.camera.it/application/xmanager/projects/leg17/attachments/upload_file/upload_files/ 000/000/189/dichiarazione_dei_diritti_internet_inglese.pdf) elaborated by a special Committee, appointed by the president of the Chamber of Deputies (on. L. Boldrini) (http://www.camera.it/leg17/1177). The Committee's work is still in progress, and is intended to provide the Italian Government with a technical and political basis for the promotion of promote an International Bill of rights. The overall results achieved so far can be considered satisfactory, although some provisions may appear to be insufficient and inadequate (see the comments of prof. De Minico, member of the Committee, in meeting n. 3, Oct. $8^{\text {th }}, 2014$, at

http://www.camera.it/application/xmanager/projects/leg17/attachments/attivita_commissione_inte rnet/files/000/000/003/resoconto_commissione_8ottobre.pdf (pp. 27-30). While this was being revised for print, the final draft of the Declaration of Interent Rights has been approved on July 28, 2015: http://www.camera.it/application/xmanager/projects/leg17/commissione_internet/testo_ definitivo_inglese.pdf. This latest version takes into account the suggestions and proposals, mine included, arising from the debate within the Committee. The results of a wide public consultation have also been considered. Conclusively, the document can be deemed to be a well-balanced compromise among different positions, as a constitutional inspiration should always bear. 
serves to be pursued and is becoming more than a purely speculative exercise.

For the reasons discussed before, such a Bill should tackle two issues. Firstly, it should state that the conflict between opposite values must be resolved according to the prevalence of individual rights over economic liberties. Secondly, it should resolve the relationship between the binding sources and self-regulation with the prevalence of the former over the latter. Reference could be made here to the European Convention of Human Rights and European Charter of Fundamental Rights to point out at least three other more specific guarantees aimed at constraining the rulemaking power of policymakers: necessity, indispensability, and proportionality, extensively recalled by the two European Courts (Eur. Ct. H.R. and ECJ). ${ }^{112}$ The language used by both is not always coincident, but it does not seem necessary to delve into the matter here. ${ }^{113}$ I simply want to underline the fact that the discretionary power of the legislator is anything but undefined both in the European and in the International case law. ${ }^{114}$

The first limit, i.e. necessity, is a one-way approach, requiring the sacrifice of a right to be accepted only if it cannot be avoided. Conversely, the sacrifice cannot be accepted if an alternative in which that

112. Paul Craig \& Grainne De Búrca, EU law. TeXts, CASES AND MATERIALs, 396-400 $\left(5^{\text {th }}\right.$ ed. 2008), in which the authors state that "Article 52(1) of the European Charter of Fundamental Rights, which draws on the jurisprudence of both the ECHR and the ECJ, contains a general derogation clause, indicating the nature of restrictions on Charter rights will be acceptable."

For a criticism to this thesis see: D. Triantafyllou, The European Charter of Fundamental Rights and the "Rule of law". Restricting fundamental rights by reference, at (2002) 39 CMLR 53

113. On the complex relationship between the ECHR and the ECJ see, from a large literature: G. Harpaz, The European Court of Justice and its relationship with the European Court of Human Rights: the question of enhanced reliance, coherence and legitimacy (2009) 46 MLR 105; F. Callewaert, The European Court Human Rights and European Union law: a long way to harmony (2009) 6 EHRLR 768-783.

114. Concerning the Eur. Ct. H.R., it has long accorded to the State Parties a margin of appraisal in making public decisions, which potentially influence ECHR (see, eg. Handyside $v$. $\begin{array}{llllll}\text { United Kingdom } & \text { (1976) } & 1 & \text { EHRR } & 737 & \text { at }\end{array}$ http://hudoc.echr.coe.int/sites/eng/pages/search.aspx?i=001-57499\#\{“itemid":["001-57499”]\}). The extent of the margin allowed by the court varies according to the policy area in question; for example, it is usually wider in economic or national security issues, and narrow in the area of criminal justice. As to the ECJ, it has also allowed Member States some discretion on their decision-making, stating that EU law does not impose upon the Member States an uniform scale of values as regards the assessment of conduct which may be considered contrary to public policy (Adoui and Cournuaille $v$ Belgium, (Cases 115 e 116/81) [1982] ECR 1665 (par. 8)) at http://eurlex.europa.eu/legal-content/EN/TXT/PDF/? uri=CELEX:61981CJ0115\&from=EN. For an extensive overview on recent cases see: E. BERRY, M. J. HOMEWOOD \& B. BOGUSZ, EU LAW 306 (OXford: Oxford University Press, 2013. 
same right remains unfettered is viable. ${ }^{115}$

The second limit, indispensability, is an instance of common ground between the Italian Constitutional Court ${ }^{116}$ and the European Court of Human Rights. ${ }^{117}$ The former has defined this limit as the "minimum essential content" for rights, up to the point of inducing part of the doctrine to consider the necessity a "limit to the limit." ${ }^{118}$ Conclusively, no such restriction is allowed as to substantially extinguish the right, no matter how essential the interest pursued by the legislator may be.

The third limit, proportionality, ${ }^{119}$ is the real test for the reasonableness of any legal provision. Costs and benefits must be assessed in order to check that a proper balance has been found between the interests embodied in the protected rights and those on which the legislative restriction is founded. ${ }^{120}$ The goal is to prevent limitations to rights, which do not grant any significant and corresponding advantage to the competing interests. ${ }^{12}$

115. See Richard Clayton \& Hugh TOMLinson, The Law OF Human Rights 339-40 (2nd ed. 2009).

116. Corte Cost., Cass., 22 febbraio 1990, 67 (It.) available at http://www.giurcost.org/decisioni/1990/0067s-90.html.

117. The determination of the objective pursued by the restriction to a fundamental right may be decisive to answer the question whether the limitation may be considered 'necessary in a democratic society', i.e. such a necessity must go beyond the mere need to achieve that aim. (See the leading case: ECHR, (plen.) Open door and Dublin Well Woman $v$. Ireland, 1992, Series A no. 246-A, par. 64, at http://hudoc.echr.coe.int/sites/eng/pages/search.aspx? $i=001$ 57789\#\{“itemid”:[“001-57789”]\})

118. Massimo Luciani, l diritti fondamentali come limiti alla revisione dela costituzione, in LIBERTÀ E GIURISPRUDENZA CONSTITUZIONALE 121-129 (Vittorio Angiolini ed., 1992). This expression is also common among Spanish scholars, ex multis, see Antonio-Luis MartínezPujalte, La garantía del contenido esencial de los derechos fundamentales, in CUADERNOS Y DEBATES 65, 6 (1997).

119. Jonas ChristofFersen, Fair Balance: Proportionality, Subsidiarity AND Primarity in the European Convention on Human Rights (2009); Alastair Mowbray, A Study of the Principle of Fair Balance in the Jurisprudence of the European Court of Human Rights, 2 Human RigHTS L. REV., 2, 289 (2010).

120. Mowbray supra note 119.

121. Court of Justice, Case C-360/10, Belgische Vereniging van Auteurs, Componisten en Uitgevers (SABAM) v Netlog NV (16 Febrary 2012), para. 51, at http://curia.europa.eu/juris/document/document.jsf?text $=\&$ docid=1 19512\&pageInd $\mathrm{ex}=0 \&$ doclang $=\mathrm{EN} \& \operatorname{mode}=1 \mathrm{st} \& \mathrm{dir}=\& \mathrm{oc}=$ first $\&$ part $=1 \& \mathrm{cid}=2210378$.

For a specific reference to data retention and electronic communications see recently:

Court of Justice (Grand Chamber) (8 April 2014), in Joined Cases C-293/12 and C-594/12, at http://curia.europa.eu/juris/document/document.jsf?docid=150642\&doclang=EN.

In particular, in the paragraphs n. 46, 69 e 70 the Court recalls its previous decisions and finds in the violation of proportionality a conclusive reason for the invalidity of Data Retention Directive (2002/58). 
A regulation which does not comply with the aforesaid principles may be found in the Hadopi 2. The law fails on at least three different grounds. Firstly, it balances heterogeneous values: a fundamental right (to access) vs. an economic interest (copyright). Secondly, it charges the former (the fundamental right) with excessive and disproportionate bounds. Finally, the restrictions laid down do not prove to be necessary. A support for this conclusion may be inferred from a report showing that the law has been unsuccessful in educating consumers to a lawful use of the Internet.

On the contrary the English High Court does not seem to share such a viewpoint: in fact, it has not hesitated to block alleged terrorist access to the Internet in order to avoid the danger of dissemination of certain ideas. ${ }^{122}$ In this judicial balancing between fundamental values, a right is denied tout court on the occurrence not of immediate and current damage, but rather of the risk of its future occurrence. ${ }^{123}$ Therefore, the High Court is disregarding two impassable limits safeguarding fundamental rights, putting the legitimacy of its ruling under European legal standards at serious risk.

Finally, I find a substantial support to my claims in the action of the ECtHR, ${ }^{124}$ as quoted above. Limitations on fundamental rights and liberties may be allowed only if indispensable, not differently avoidable, and a correct and proportionate balance is found between the competing interests. This clear conclusion should contribute to the core of an Internet Bill such as it is proposed in this paper. More detailed rules could be left to self-regulation, in coherence with the opinion - set forth in this paper - that maintaining the legally binding rules to a minimum is the best choice for the Internet.

\section{EQUALITY ON THE INTERNET: MYTH OR REALITY?}

I have underlined the need for a "Bill of Rights" tailored to the Internet, entrusted to a supranational legislator. I wish to point out now that two preliminary requirements should be met.

Firstly, the legislator should resort in its own rulemaking to self-defining concepts rather than to general clauses, and to substantive regulation instead of uncertain and general principles inevitably in need of broad interpretations. Secondly, the legislator should re-

122. AM vs. Secretary of State for the Home Dept. [2001] EWHC 2486 A.C. available at www.bailii.org..

123. Id.

124. Infra at 115,117 and 119. 
turn each actor, be it public or private, to its own domain, returning political choice to the policy-makers, wresting it back both from Independent Authorities and private powers, to which it has been entrusted through a broad delegation by policy-makers. This approach would allow Authorities to be entrusted with tasks more appropriate to their institutional position, involving no political responsibility. At the same time, the judicial power would be called to apply rules sufficiently defined in their content, enforcing the political project sketched out by the legislator, rather than starting one ex novo.

A final question arises: is there a set of values, which the legislator will have to accept and enforce in drawing up a discipline well suited to the Internet? In my opinion, such a set of values does exist even now: it is made up of the principles of modern constitutionalism commonly shared in the European and Anglo-American experience, although it is clear that these principles must be rethought on the basis of the peculiarities of the Internet. ${ }^{125}$

The first and paramount value to be taken into account is equality, which should thus be the keystone of a regulatory framework for the Internet. The virtual world is - no less than the real one - marked by strong inequalities, to be compensated with asymmetric regulation in bonam partem. ${ }^{126}$ This concept leads to rules intended to promote weaker social categories in need of an additional protection in order that a greater equality may be effectively pursued.

This is the foremost challenge of the Internet.

The infinite possibilities of a better quality of life, better services, greater knowledge generated by the network must represent a chance for social redemption for those who so far have not been allowed to share economic prosperity and social inclusion. This is even more important because - in a world marked by increasing inequalities, which are a serious threat to the future of us all - the network proposes itself as the only tool potentially able to reverse the trend, even offering a new model of peaceful coexistence. In this sense, Internet can become the cornerstone of modern democracies, no less than the freedom of speech and of the press has already been in the

125. In the same direction indicated above see J. Rowbottom, In the shadow of the Big Media: Freedom of expression, Participation and the Production of Knowledge Online, 3 PUBLIC LAW, 509 (2014).

126. Giovanna De Minico, The 2002 EC Directives Telecommunications: Regime up to the 2008 Ongoing Revision - Have the Goals been Reached? 19 EuR. Bus. L. REV. 657, 658-59 (2008). 
past.

The goal of equality means that the Internet must be redeemed from the narrow image of a 'land' populated only by selfish myths of liberalism. Internet must be defended as the largest public space that humanity has ever had to gain experience of civic virtues and policies.

The issue of equality can be summarized in the right for citizens to access the Internet, for operators to next generation networks and, ultimately, for consumers to services. ${ }^{127}$ The right of citizens' access consists in the universal provision of fast connection, regardless of location or income of the net-citizens. The right of operators aims to assure that network architecture is easily accessible to the non-owner operators. The right of the consumers to services meets the need to provide consumers with a broad choice between plural products offered by different economically independent entrepreneurs, in opposition to the substantial oligopoly of the giants of the network.

The goal of equality can only be pursued fighting powerful enemies. Its achievement is not a natural and predictable outcome of technical progress, which is not inherently oriented in a unique and predetermined direction. I am disputing the argument that the so called Lex Informatica ${ }^{128}$ could be a primary and automatic source of a rule-making oriented per se and by default to the common good. Such a result may be obtained only if the policymaker has pursued equality as a specific goal, and has consequently provided effective means to achieve it. The preliminary choice of the goal that the technique should achieve belongs to the author of the rule, together with the accountability for the choice itself.

The best choice is found focusing on the recipient of the benefit provided by the technique. Should it be the weaker subject, or the already stronger one? In the first case, the technique will be the driving force for socially well-distributed growth; in the second case, the same will be the multiplier of well-being in favour of those who are already advantaged per se.

I can find immediate examples in the access to the broadband, not yet promoted as a universal service; in the architecture of the

127. Another work develops a wider and more comprehensive analysis of equality and the Internet: G. De Minico, INTERNET. REGOlA E ANARCHIA [INTERNET. RULES AND ANARCHY], chapters II and III.

128. Joel R. Reidenberg, Lex Informatica: The Formulation of Information Policy Rules through Technology, 76 TEX. L. REV. 553, 555 (1998). 
Next generation networks designed in favour of the ex-incumbent; or in the absence of regulation to guarantee net neutrality. ${ }^{129}$ The examination of national legislation and implementation measures is disappointing, since it shows that the conflict between the under-protected categories - such as new operators, netizens, children - and the economic interests of communication enterprises has been basically resolved in favour of the latter. ${ }^{130}$ The law of the market seems to have won in the end. Because of that, the weaker parties do not receive the additional protection that they would deserve in accordance with the network promoted as the new lever of modern constitutionalism. To this end, what should the supranational legislator do?

As a priority, asymmetrical rules should be adopted with the purpose of reversing the current trend in favour of adult users, operators in dominant position, citizens already provided with a connection. The regulatory focus should be re-oriented in favour of children, neo-entrants entrepreneurs and citizens who cannot afford a connection at market prices.

The unbalanced relationship now in existence between the weak categories and communication enterprises is to be overturned. This would also be in accordance with the social mission to such enterprises should in principle already obey. ${ }^{131}$ The point is that the com-

129. The theme of net neutrality would deserve an autonomous work. Within the scope of this essay I refer to note 38 for its definition and to notes 39 and 40 for recent developments due to the procedures pending before F.C.C.. For a closer examination see especially: S. Zack, REGUlating THE WEB: NETWORK NEUTRALITY AND THE FATE OF THE OPEN INTERNET, (Plymouth: Lexington Books, 2013); A.C. Firth . - N. H. Pierson. (eds), THE OPEN INTERNET, NET NEUTRALITY AND THE FCC (New York: Nova Science Publishers, 2011); T. W. Hazlett., THE FALlACY OF NET NEUTRALITY, (New York: Encounter Books, 2011); C. T. Marsden, NET NEUTRALITY: TOWARDS A CO-REGULATORY SOLUTION, (London: Bloomsbury Academic, 2010); D. C. Nunziato Virtual freedom: net neutrality and free speech in the Internet age, (Stanford: California Stanford Law Books, 2009); J. Zittrain, THE FUTURE OF THE INTERNET-AND How TO STOP IT, (New Haven - London: Yale University Press, 2009).

130. Should it still be necessary, a further example may be found in the issue between the protection of the children and the promotion of the enterprises operating in Internet. In this querelle the former value has been sacrificed in favour of economic interests. In fact, the protections against offence speeches and hard images offered by filters have not been enough, the autodeclaration of the age requested by Facebook and Twitter is ridiculous, the selective surf is not practicable. These defeatsare not due to a deficiency of technique, but to the weakness of political projects in favour of children as compared with the strong economic interests involved. I have dealt with this issue in a previous essay: 'Il favor constitutionis e il minore: realtà o fantasia?' (The Favor Constitutionis and the child: reality or mere fantasy? at G. De Minico (ed), Nuovi media e minori, [New Media and children] (Roma: Aracne, 2012) 35-42.

131. I refer to a "social mission" because this particular organization of persons and means operates in the market of ideas. So it has a direct effect on the process of shaping individual consciences and public opinion in general. Such a scope justifies the particular regime, which this 
munication enterprises have been detached from the common good following an incorrect concept of the market economy that reduces public intervention to ultra-minimal standards. We are currently facing a poor imitation of the Smithian chimera of an automatic harmony between public and individual interests: a myth to which not even Smith - in my opinion - seemed to believe fully.

New concepts are required if the Internet is to be regulated in coherence with the values of equality and individual rights. These values are the only ones able to ensure that technological progress ends up in a chance of growth for all, aligning the weak categories with the wellfunded ones, something that up to now has been real only in the world of dreams.

kind of enterprise should be submitted to.

132. G. Kennedy, Adam Smith and the Invisible Hand: From Metaphor to Myth 6 ECON. JOURNAL WATCH, 2, 250 (2009). The author clearly explains that Smith had never said that public and private interests could combine each other by the default "wholly misleading belief of how commercial markets function", because instead the intervention of the State would be necessary to this end. For a different perspective see: D. B. Klein, In Adam Smith's Invisible Hands: Comment on Gavin Kennedy 6 ECON JOURNAL WATCH, 2,264-279 (2009). 